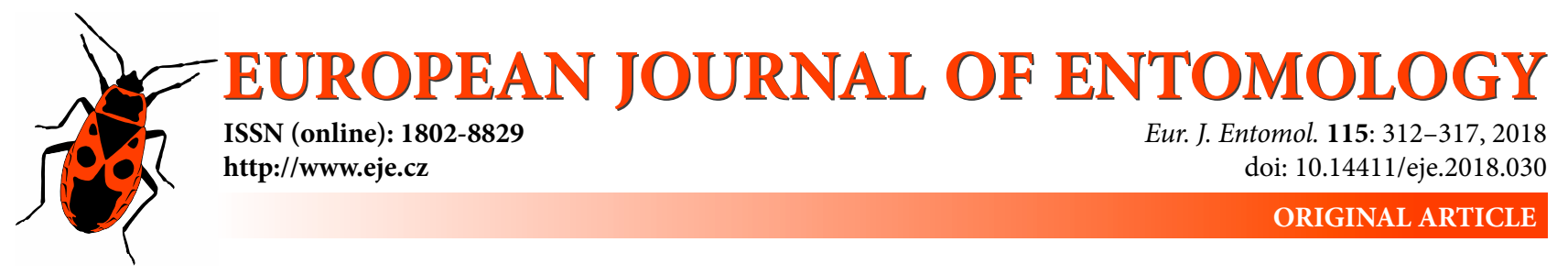

\title{
Evaluation of responses of different ant species (Formicidae) to the scavenger deterrent factor associated with the entomopathogenic nematode-bacterium complex
}

\author{
Baris GULCU ${ }^{1}$, Selcuk HAZIR ${ }^{2}$, Edwin E. LEWIS ${ }^{3}$ and HARRY K. KAYA ${ }^{4}$ \\ ${ }^{1}$ Department of Biology, Faculty of Arts and Sciences, Duzce University, 81620, Duzce, Turkey; \\ e-mail: barisgulcu@duzce.edu.tr \\ ${ }^{2}$ Department of Biology, Faculty of Arts and Sciences, Adnan Menderes University, 09010, Aydin, Turkey; \\ e-mail: selcuk.hazir@gmail.com \\ ${ }^{3}$ Department of Entomology, Plant Pathology and Nematology, University of Idaho, 83843, Moscow, ID, USA; \\ e-mail: eelewis@uidaho.edu \\ ${ }^{4}$ Department of Entomology and Nematology, University of California, 95616, Davis, CA, USA; e-mail: hkkaya@ucdavis.edu
}

Key words. Ants, Formicidae, scavenger deterrent factor, pathogens, Heterorhabditis, Photorhabdus

\begin{abstract}
According to previous observations, it was hypothesized that the feeding behavior of some ant species would be deterred by a scavenger deterrent factor (SDF), whereas for other species it would not. The effects of the SDF were studied on 11 ant species in three different subfamilies: Dolichoderinae Forel, 1878, Formicinae Latreille, 1809, and Myrmicinae Lepeletier de Saint-Fargeau, 1835. The experiments were conducted from 2014-2015 in Davis, California, United States, Aydin, Turkey, and Duzce, Turkey. Five-day-old Heterorhabditis bacteriophora (Poinar, 1976), (Hb)-killed and freeze-killed Galleria mellonella (Linnaeus, 1758) were exposed to ant colonies in the field for 3 to $4 \mathrm{~h}$. Seven ant species fed significantly less on $\mathrm{Hb}$-killed insects than freeze-killed insect. On the other hand, there was no significant difference in cadaver consumption with five species, but Liometopum occidentale Emery, 1895 did consume a higher rate of $\mathrm{Hb}$-killed insects than freeze-killed insects and was not deterred by SDF. It was also observed that four ant species took $\mathrm{Hb}$-killed insects into the nests, but two Myrmicinae species, Pogonomyrmex subdentatus Mayr, 1870 and Messor meridionalis (André, 1883) removed the cadavers after 30 min, whereas two Formicinae species, Cataglyphis nodus (Brullé, 1833) and Formica fusca Linnaeus, 1758, retained the cadavers in the nest. It was assumed that the latter two species consumed both $\mathrm{Hb}$-killed and freeze-killed insects. Further studies are needed to explain why L. occidentale C. nodus and F. fusca are not deterred by SDF.
\end{abstract}

\section{INTRODUCTION}

The scavenger deterrent factor (SDF) is an unidentified chemical compound(s) associated with insects killed by the entomopathogenic nematode-bacterium complex. This SDF affects scavengers and/or omnivores like ants (Baur et al., 1998; Zhou et al., 2002) crickets, cockroaches, springtails, vespid wasps, and calliphorid flies (Gulcu et al., 2012; Ulug et al., 2014), predatory insects (Foltan \& Puza, 2009; Jones et al., 2016), an insectivorous bird (Fenton et al., 2011), and more recently three cyprinid fish species (Ramalingam et al., 2017) and results in complete rejection or only partial consumption of nematode-killed insects. Zhou et al. (2002) demonstrated that the deterrent effect on scavenger ants was associated with the mutualistic bacterial genera, Photorhabdus (Boemare et al., 1993) (Enterobacteriaceae) and Xenorhabdus Thomas \& Poinar, 1979 (Enterobacteriaceae) of entomopathogenic nematodes (EPNs) and referred to the compound(s) as an
“Ant Deterrent Factor" (ADF). Subsequently, Gulcu et al. (2012) reported that ADF not only deters several ant species but also repelled crickets, vespid wasps and calliphorid flies from feeding on nematode-killed insects, and they renamed it SDF because it had a wider effect on different species of scavenger insects.

EPNs are in the families Heterorhabditidae, Poinar, 1975 (Nematoda: Rhabditida) and Steinernematidae, Nguyen \& Smart, 1994 (Nematoda: Rhabditida) and as stated above, have a mutualistic relationship with bacteria in the genera Photorhabdus (Heterorhabditis) and Xenorhabdus (Steinernema) (Kaya \& Gaugler, 1993). In the EPN-bacterium life cycle, the 3rd stage infective juvenile (IJ) seeks an insect host in the soil, enters via natural openings (mouth, anus or spiracle), penetrates into the host's hemocoel and releases the bacterial cells that are sequestered in the IJ's intestine (Adams \& Nguyen, 2002). The bacteria multiply and kill the host by septicemia in $24-48 \mathrm{~h}$ (Hazir et 
al., 2003; Boemare \& Akhurst, 2006). After infection, the nematodes develop to adults and it takes a week or more before the newly produced IJs emerge to seek out new hosts.

During bacterial multiplication in the insect host, a variety of small molecules are produced that protect the cadaver from bacterial and fungal contamination (Boemare \& Akhurst, 2006; Hinchliffe et al., 2010; Tobias et al., 2017) as well as invertebrates and some vertebrates (Baur et al., 1998; Foltan \& Puza, 2009; Fenton et al., 2011; Gulcu et al., 2012; Jones et al., 2016; Ramalingam et al., 2017). Possibly, SDF is a small molecule (s) within the anthraquinones (AQs) which are ecologically important metabolites for Photorhabdus and appear to protect nematode-killed insects more than metabolites from Xenorhabdus that does not have AQs (Pankewitz \& Hilker, 2008; Bode, 2009; Gulcu et al., 2012; Ulug et al., 2014).

Ants (Hymenoptera: Formicidae) are one of the most successful groups of eusocial insects in the world (Fittkau \& Klinge, 1973). They are important as scavengers, herbivores, or predators and show highly specialized behaviors like farming fungi, harvesting seeds, herding and milking of other insects (e.g., aphids), communal nest weaving, cooperative hunting in packs, social parasitism and slavemaking (Hölldobler \& Wilson, 1990). Other species are omnivores feeding on a variety of food sources. Studies conducted by Baur et al. (1998), Zhou et al. (2002), Gulcu et al. (2012), and Ulug et al. (2014) showed that several ant species do not feed on Steinernema- or Heterorhabditis-killed insects that were more than 2-days old and heterorhabditids produce a stronger deterrent factor than steinernematids. Some scavenger species, such as ants and crickets, partly consume 2-day-old Steinernema-killed insects but not Heterorhabditis (Gulcu et al., 2012; Ulug et al., 2014). Recently, it was observed that two ant species, Cataglyphis nodus (Brullé, 1833) (Hymenoptera: Formicidae) and Liometopum occidentale Emery, 1895 (Hymenoptera: Formicidae), did consume Heterorhabditis-killed insects. Accordingly, it was hypothesized that the response of ants to SDF varied by species and we report herein a quantitative study to determine differential responses of several ant species to SDF in Heterorhabditis-killed insects.

\section{MATERIAL AND METHODS}

\section{Nematodes and infection of larvae}

The EPN, Heterorhabditis bacteriophora $(\mathrm{Hb})$ (Bakersfield strain) (Poinar, 1976) (Nematoda: Rhabditida) was used in the experiments in USA and in Turkey. This nematode strain was maintained in Dr. Edwin E. Lewis' laboratory in the Department of Entomology \& Nematology, Davis, California. The nematode was cultured using last instar Galleria mellonella (Linnaeus, 1758) (Lepidoptera: Pyralidae) larvae at $23-24^{\circ} \mathrm{C}$ according to Kaya \& Stock (1997). The $H b$-killed larvae were transferred to a White trap, and emerging IJs were harvested from the water (White, 1927) and stored at $15^{\circ} \mathrm{C}$ for no more than 3 weeks when they were used to infect the test insects.

To obtain the nematode-killed larvae for field studies, $10 \mathrm{G}$. mellonella were exposed to $100 \mathrm{IJ} /$ /larva in a plastic petri dish $(100 \times 15 \mathrm{~mm})$ lined with a filter paper. Petri dishes were placed in plastic bags to maintain moisture and kept at $25^{\circ} \mathrm{C}$ for 5 days.

\section{Ant colonies}

Twelve ant colonies representing 11 species in three subfamilies were observed for their response to nematode-killed insects (Table 1). Ant species from the USA and Turkey were identified by Dr. Phillip S. Ward, University of California-Davis, Department of Entomology and Nematology, and Dr. Kadri Kiran, Trakya University, Department of Biology, respectively. Six of the colonies were from Davis, California, USA and the other six of were from Duzce, and Aydin, Turkey.

Of the 12 colonies, two were colonies of Tetramorium cf. caespitum (Linnaeus, 1758) (Hymenoptera: Formicidae); one collected in California and the other from Turkey (Table 1).

\section{Experimental design}

Four G. mellonella cadavers were pinned on a piece of cardboard $(10 \mathrm{~cm} \times 12 \mathrm{~cm})$ and placed nearby ant nests or trails. (See Fig. 1 for arrangement of cadavers on cardboard.) The color of cardboards was brownish which is similar to the color of the soil. Two cadavers were five-day-old $H b$-killed and two were freezekilled larvae. Five-day-old EPN-killed cadavers were used because in the previous studies, the highest SDF activity was reported after four days (Gulcu et al., 2012). The experiments were repeated three times for each ant species. The cadavers were placed out in the field for 3 to $4 \mathrm{~h}$ between 0600 and $1100 \mathrm{~h}$, or in the late afternoon between 1500 and $2000 \mathrm{~h}$ in a shaded location in summer of 2014 and 2015. Ant activity was observed hourly over the $3 \mathrm{~h}$ period, but in four cases, we observed that Pogonomyrmex subdentatus Mayr, 1870 (Hymenoptera: Formicidae), Messor meridionalis (André, 1883) (Hymenoptera: Formicidae), C. nodus and Formica fusca Linnaeus, 1758 (Hymenoptera: For-

Table 1. Ant species (common names) and colony locations used in the experiments.

\begin{tabular}{|c|c|c|c|}
\hline Subfamily & Ant species (Common name) ${ }^{\star}$ & Location & Coordinates \\
\hline Dolichoderinae & Dorymyrmex insanus & Davis, CA, USA & $38^{\circ} 32^{\prime} 19.57^{\prime \prime} \mathrm{N}, 121^{\circ} 45^{\prime} 54.13^{\prime \prime} \mathrm{W}$ \\
\hline Dolichoderinae & Linepithema humile (Argentine ant) & Davis, CA, USA & $38^{\circ} 32^{\prime} 20.13^{\prime \prime} \mathrm{N}, 121^{\circ} 45^{\prime} 57.64^{\prime \prime} \mathrm{W}$ \\
\hline Dolichoderinae & Liometopum occidentale (Velvetry ant) & Davis, CA, USA & $38^{\circ} 31^{\prime} 48.30^{\prime \prime} \mathrm{N}, 121^{\circ} 46^{\prime} 3.23^{\prime \prime} \mathrm{W}$ \\
\hline Dolichoderinae & Tapinoma erraticum (Erratic ant) & Duzce, Turkey & $45^{\circ} 53^{\prime} 10.19^{\prime \prime} \mathrm{N}, 31^{\circ} 12^{\prime} 08.11^{\prime \prime} \mathrm{E}$ \\
\hline Formicinae & Cataglyphis nodus & Duzce, Turkey & $40^{\circ} 56^{\prime} 28.16^{\prime \prime} \mathrm{N}, 31^{\circ} 22^{\prime} 11.04^{\prime \prime} \mathrm{E}$ \\
\hline Formicinae & Formica fusca & Duzce, Turkey & $40^{\circ} 54^{\prime} 20.98^{\prime \prime} \mathrm{N}, 31^{\circ} 11^{\prime} 02.91^{\prime \prime} \mathrm{E}$ \\
\hline Myrmicinae & Monomorium ergatogyna & Davis, CA, USA & $38^{\circ} 32^{\prime} 17.79^{\prime \prime} \mathrm{N}, 121^{\circ} 44^{\prime} 37.03^{\prime \prime} \mathrm{W}$ \\
\hline Myrmicinae & Messor meridionalis & Duzce, Turkey & $40^{\circ} 56^{\prime} 27.23^{\prime \prime} \mathrm{N}, 31^{\circ} 22^{\prime} 10.52^{\prime \prime} \mathrm{E}$ \\
\hline Myrmicinae & Pogonomyrmex subdentatus & Davis, CA, USA & $38^{\circ} 32^{\prime} 19.10^{\prime \prime} \mathrm{N}, 121^{\circ} 45^{\prime} 54.68^{\prime \prime} \mathrm{W}$ \\
\hline Myrmicinae & Tetramorium cf. Caespitum (Pavement ant in Davis) ${ }^{\star *}$ & Davis, CA, USA & $38^{\circ} 32^{\prime} 50.06^{\prime \prime} \mathrm{N}, 121^{\circ} 46^{\prime} 27.49^{\prime \prime} \mathrm{W}$ \\
\hline Myrmicinae & Tetramorium cf. caespitum (Pavement ant in Duzce) $)^{\star *}$ & Duzce, Turkey & $45^{\circ} 53^{\prime} 10.19^{\prime \prime} \mathrm{N}, 31^{\circ} 12^{\prime} 08.11^{\prime \prime} \mathrm{E}$ \\
\hline Myrmicinae & Tetramorium chefketi & Aydin, Turkey & $37^{\circ} 51^{\prime} 18.80^{\prime \prime} \mathrm{N}, 27^{\circ} 51^{\prime} 15.97^{\prime \prime} \mathrm{E}$ \\
\hline
\end{tabular}




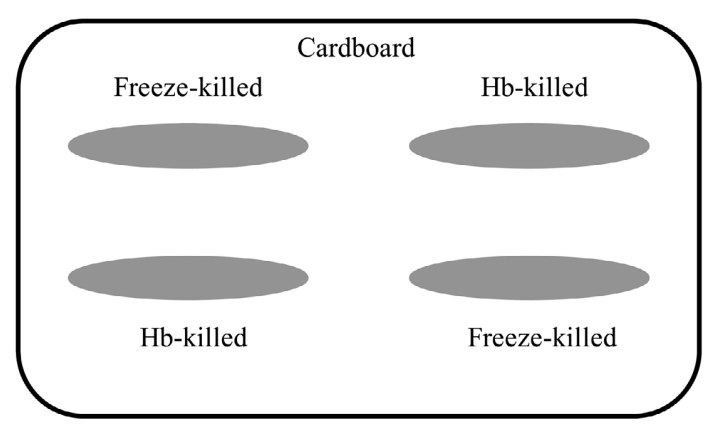

Fig. 1. Arrangement of cadavers on cardboard. $\mathrm{Hb}=$ Heterorhabditis bacteriophora.

micidae) workers demonstrated different behaviors compared with the other six ant species. Therefore, these ant species were observed for an additional hour. In the experiments, each cadaver had its weight recorded using a precision scale before pinning on cardboard. After 3 or $4 \mathrm{~h}$, the cadavers that were not completely consumed were brought to the laboratory, re-weighed and examined under the dissecting microscope to determine the extent of ant feeding activity. To measure the level of potential deterrent effect on each ant species, we compared the larval weight loss of $\mathrm{Hb}$-killed and freeze-killed cadavers. Statistical difference between these two groups indicated that a certain ant species responded to SDF. If there was no statistically significant difference, it was accepted that the ant species was unaffected by SDF produced.

\section{Statistical analysis}

Response of ants to $H b$-killed or freeze-killed insects were performed by using independent sample t-test with IBM, SPSS Statistics version 22.0 within each species. Weight reductions were compared at the $\mathrm{P}=0.05$ level (SPSS, 2013). Percent weight reduction data were arcsine transformed before statistical analyses.
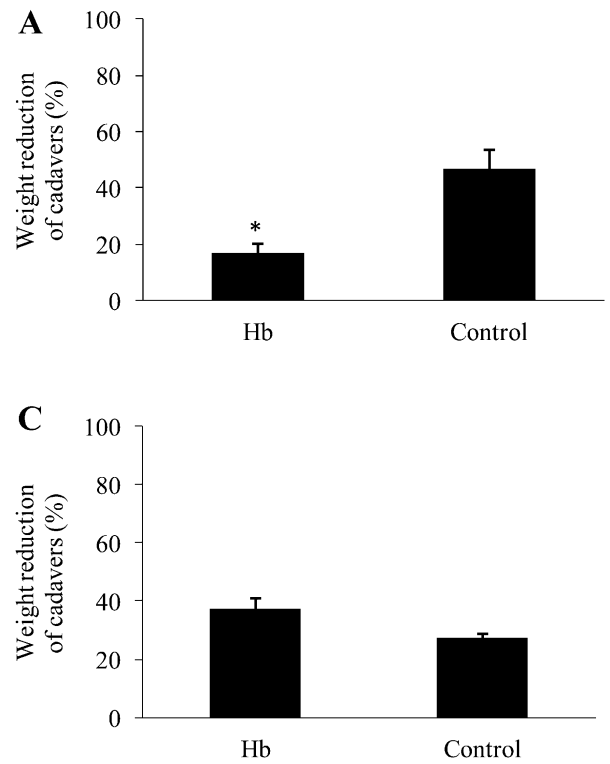

\section{RESULTS AND DISCUSSION}

The loss of cadaver weight at the end of each experiment was determined to evaluate ant feeding activity. This approach differed from previous research in which Baur et al. (1998) and Zhou et al. (2002) classified the cadavers as intact or not intact according to breaks in the integument. They compared the number of intact cadavers belonging to each group in the treatments after $24 \mathrm{~h}$. Furthermore, Gulcu et al. (2012) and Ulug et al. (2014) examined the extent of cadaver consumption after 12 and $3 \mathrm{~h}$, respectively, by visual examination using a dissecting microscope at $20 \times$ and estimating the percentage of each cadaver that was consumed. In our study both visual examination and weight loss observed in cadavers were considered.

Using the loss of cadaver weight, we found significantly more of the freeze-killed insects were consumed than the $\mathrm{Hb}$-killed insects in the following eight ant species (Figs 2-4). Interestingly, our data with $T$. cf. caespitum colony from Davis differed from the $T$. cf. caespitum colony from Duzce. That is, significant differences were observed between $H b$-killed and freeze-killed insects for $T$. cf. caespitum colony Davis, but no significant differences were observed for $H b$-killed or freeze-killed insects for $T$. cf. caespitum colony Duzce. Yet, the weight loss for $H b$-killed insects for the Davis and Duzce colonies were similar. In this case, statistical differences or lack of it may be an artifact. On the other hand, Zhou et al. (2002) suggested that the difference in cadaver consumption might originate from colony size and/or weather conditions.

Different feeding behaviors with $C$. nodus, F. fusca, $P$. subdentatus and $M$. meridionalis which took the $H b$-killed insects into their nests were observed. But P. subdentatus and $M$. meridionalis removed and discarded the $H b$-killed
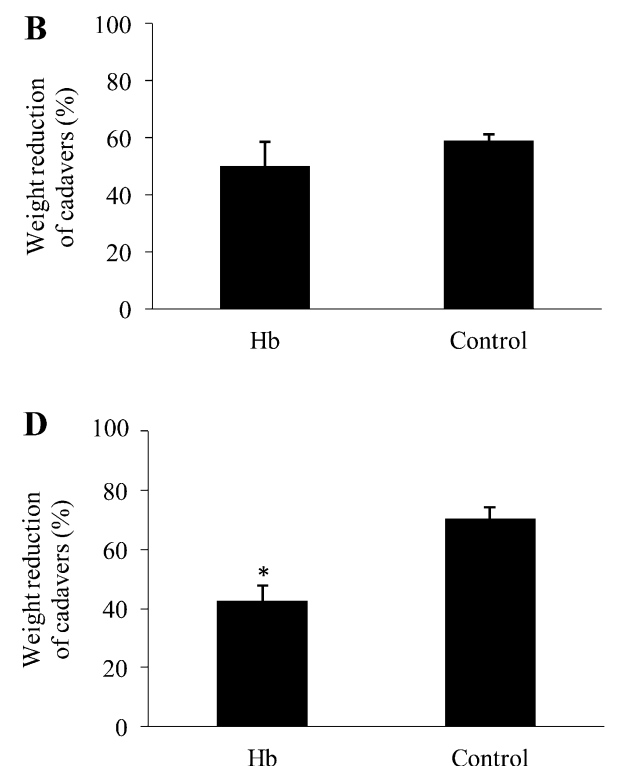

Fig. 2. Larval weight reduction of $H$. bacteriophora-killed and freeze-killed insects by four species of subfamily Dolichoderinae. $\left({ }^{*}\right)$ indicates the significant difference between nematode-killed and freeze-killed groups for each ant species. This symbol also shows which ant species respond to SDF. The weight loss was determined by recording the weights of cadavers before and after treatments. $H b=H$. bacteriophora-killed insects; Control = freeze-killed insects. A $-T$. erraticum $(t=3.866 ; \mathrm{df}=1 ; P<0.05)$; B $-L$. humile $(t=1.012 ; \mathrm{df}=1$; $P=0.351) ; \mathrm{C}-$ L. occidentale $(t=2.500 ; \mathrm{df}=1 ; P=0.069) ; \mathrm{D}-D$. insanus $(t=4.316 ; \mathrm{df}=1 ; P<0.05)$. 

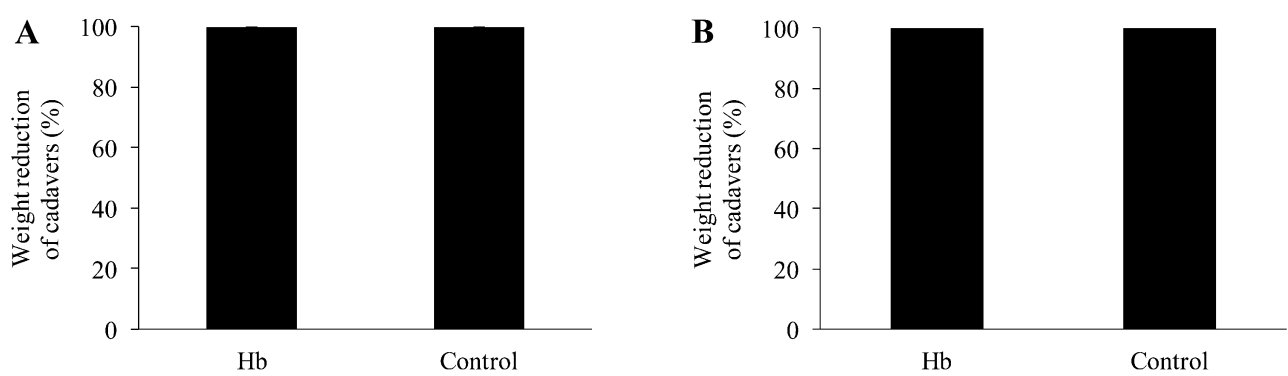

Fig. 3. Larval weight reduction of $H$. bacteriophora-killed and freeze-killed insects by two species of subfamily Formicinae. $\left(^{*}\right)$ indicates the significant difference between nematode-killed and freeze-killed groups for each ant species. This symbol also shows which ant species respond to SDF. The weight lost was determined by recording the weights of cadavers before and after treatments. $\mathrm{Hb}=\mathrm{H}$. bacteriophorakilled insects; Control $=$ freeze-killed insects. $A-C$. nodus $(t=0.000 ; d f=1 ; P=1.00) ; B-F$. fusca $(t=0,00 ; d f=1 ; P=1.00)$.

insects a short distance outside the nests usually within 30 min, whereas $C$. nodus and $F$. fusca also took $H b$-killed insects into the nest but did not remove the cadavers even after $3 \mathrm{~h}$. We made another observation at $4 \mathrm{~h}$ after experimental set up and no cadavers were found outside the nest of $C$. nodus and F. fusca. It was assumed that these cadavers were consumed by $C$. nodus and $F$. fusca within the nest
(Fig. 3). As far as we are aware, the only other invertebrate scavenger that consumed all heterorhabditid- and steinernematid-killed insects was the mite, Sancassania polyphyllae (Acari: Acaridae) (Ekmen et al., 2010a, b). Oi \& Pereira (1993) classified the removal behavior of ants as hygiene of nest and pathogen avoidance. For instance, Solenopsis invicta, Buren, 1972 (Hymenoptera: Formicidae) (Storey,
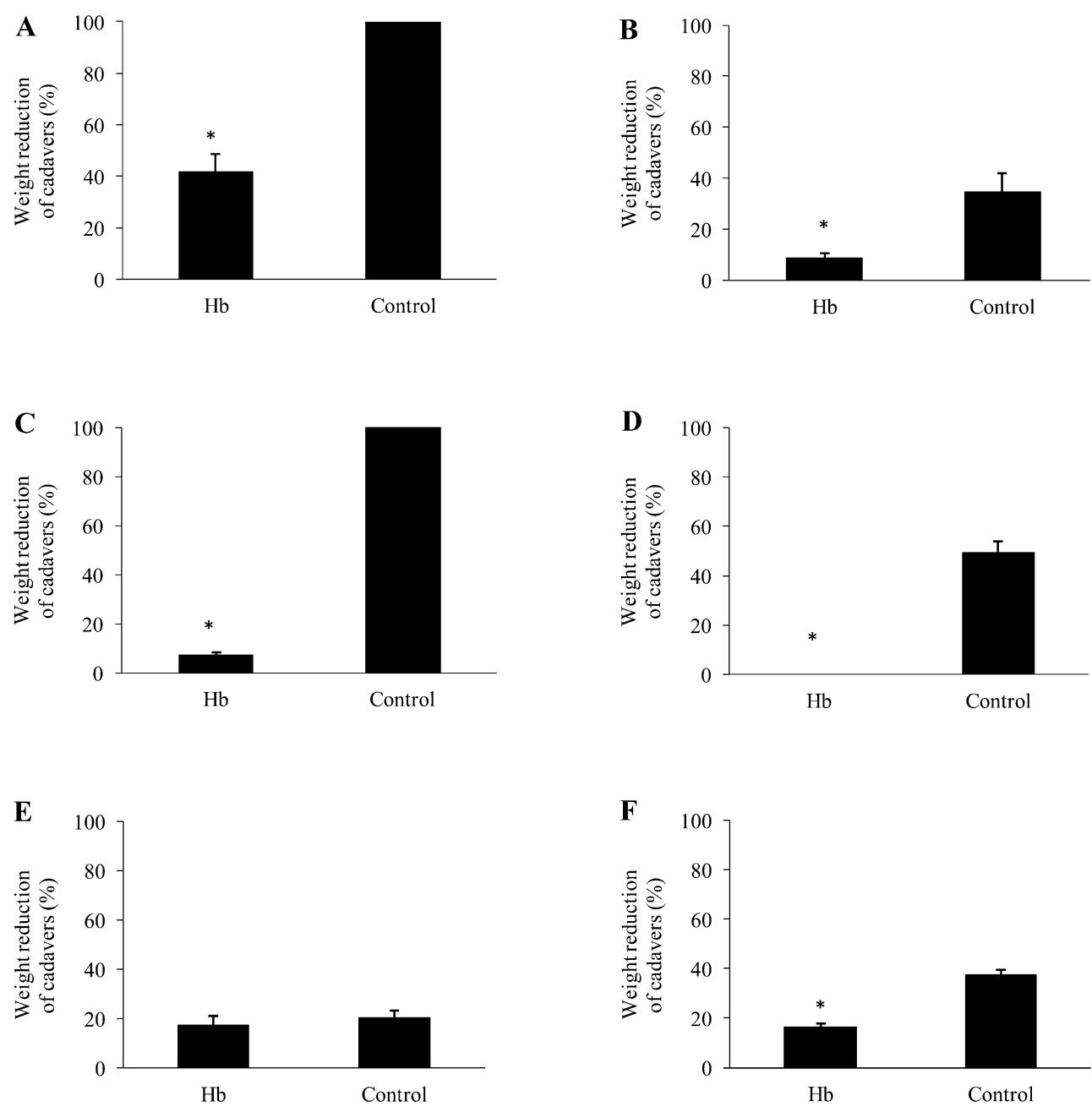

Fig. 4. Larval weight reduction of $H$. bacteriophora-killed and freeze-killed insects by six species of subfamily Myrmicinae. $\left(^{*}\right)$ indicates the significant difference between nematode-killed and freeze-killed groups for each ant species. This symbol also shows which ant species respond to SDF. The weight lost was determined by recording the weights of cadavers before and after treatments. $\mathrm{Hb}=\mathrm{H}$. bacteriophorakilled insects; Control $=$ freeze-killed insects. $A-P$. subdentatus $(t=15.445 ; d f=1 ; P<0.05) ; B-M$. ergatogyna $(t=3.561 ; d f=1 ; P<$ $0.05) ; \mathrm{C}-\mathrm{M}$. meridionalis $(\mathrm{t}=174.058 ; \mathrm{df}=1 ; \mathrm{P}<0.05) ; \mathrm{D}-\mathrm{T}$. chefketi $(\mathrm{t}=10.513 ; \mathrm{df}=1 ; \mathrm{P}<0.05) ; \mathrm{E}-T$. cf. caespitum colony Duzce $(\mathrm{t}=0.764 ; \mathrm{df}=1 ; \mathrm{P}=0,474) ; \mathrm{F}-\mathrm{T}$. cf. caespitum colony Davis $(\mathrm{t}=9.462 ; \mathrm{df}=1 ; \mathrm{P}<0.05)$. 
1990; Siebeneicher et al., 1992; Pereira \& Stimac, 1992) removed insects that were killed by the entomopathogenic fungus, Beauveria bassiana Vuill. 1912 (Hypocreales: Cordycipitaceae) from nests and Cephalotes atratus (Linnaeus, 1758) (Hymenoptera: Formicidae) removed individuals killed by the entomopathogenic fungus, Cordyceps sp. (Hypocreales: Cordycipitaceae) (Evans, 1982; Evans \& Samson, 1982). In terms of the behavior of $C$. nodus and F. fusca, another Cataglyphis sp. Foerster, 1850 in Aydin, Turkey exhibited similar behavior (Gulcu, unpubl. data) of not removing nematode-killed insects from the nest. Furthermore, those insects that were not taken into the nests, were totally consumed by $C$. nodus and $F$. fusca suggesting that the cadavers were consumed, regardless of location. In addition, Baur et al. (1998) observed that the larger ant species [Veromessor andrei (Mayr, 1886) (Hymenoptera: Formicidae) and Formica pacifica Francoeur, 1973] carried nematode-killed insects into their nest, but the fate of the cadavers within the nest was not reported.

We also observed that L. occidentale showcased an unusual feeding behavior. The parasitoid phorid flies (see Porter et al., 1995a; Feener, 2000) interrupted the feeding activity of $L$. occidentale foragers. The foraging ants assumed a defensive posture by elevating their front legs and mandibles. The foraging ants not under attack moved the cadavers under the cardboard during the $3 \mathrm{~h}$ experimental period. Furthermore, these ants were unable to complete their feeding activity on $\mathrm{Hb}$-killed and freeze-killed insects even though they attacked both groups.

Although the number of ant species tested for their response to $H b$-insects was small, we attempted to determine whether there were trends within an ant subfamily. Ant species in Dolichoderinae [i.e., Dorymyrmex insanus (Buckley, 1866) (Hymenoptera: Formicidae), Linepithema humile (Mayr, 1868) (Hymenoptera: Formicidae), L. occidentale, Tapinoma erraticum (Latreille, 1798) (Hymenoptera: Formicidae)] are known as opportunistic predators and granivores and their diets are varied. The foragers will also feed on insect and vertebrate carcasses or imbibe honeydew or any nutritious liquids they encounter (Human \& Gordon, 1996; Cuezzo, \& Guerrero, 2012; Hoey-Chamberlain \& Rust, 2014). Myrmicinae ants [i.e., T. caespitum and Monomorium pharaonis (Linnaeus, 1758) (Hymenoptera: Formicidae)] were reported as generalists (Brian et al., 1967) or omnivores (Drees \& Jackman, 1998). The subfamily Formicinae has many taxa that are well-known as wood ants (Formica), carpenter ants (Camponotus), weaver ants (Oecophylla), and honeypot ants (Myrmecocystus) (Ward et al., 2016). The diet of the subfamily members varies, but diet of the species (F.fusca and C. nodus) in our study were reported as predating small insects, feeding on floral nectaries, collecting aphid honeydew and seeds (Collingwood, 1979; Sudd \& Franks, 2013).

In this respect, variable responses were observed with Dolichoderinae ants in our study (Fig. 2). For example, $D$. insanus and T. erraticum consumed less of the $\mathrm{Hb}$-killed insects compared to the freeze-killed insects. There was no statistical difference in consumption between $\mathrm{Hb}$ - and freeze-killed insects for the Argentine ant (L. humile), and the velvety ant (L. occidentale) was the only species that consumed more $\mathrm{Hb}$-killed insects than the freeze-killed insects. Baur et al. (1998) reported that several ant species including L. humile, $V$. andre, Pheidole vistana Forel, 1914 (Hymenoptera: Formicidae), F. pacifica, and Monomorium ergatogyna Wheeler W.M., 1904 (Hymenoptera: Formicidae) scavenged nematode-killed insects. And they observed that $L$. humile scavenged $10-20 \%$ of heterorhabditid-killed insects. But in our study, there was no significant difference between consumption of heterorhabditid-killed $(50.1 \%)$ and freeze-killed insects (59\%). This discrepancy in the response of $L$. humile to $H b$-killed insects might be derived from using different nematode-bacterium strains or evaluation methods. Some ant colonies might have already had a contact with $H$. bacteriophora killed insects and probably were "conditioned" to react to different cues they come across. This could also explain the different colony responses observed for the same species.

Most Myrmicinae ants consumed less $H b$-killed insects than freeze-killed insects (Fig. 4). In fact, $H b$-killed insects were intact after exposure to Tetramorium chefketi Forel, 1911 (Hymenoptera: Formicidae) for $3 \mathrm{~h}$, whereas the freeze-killed insects were close to $50 \%$ consumed. Ulug et al. (2014) obtained similar results for T. chefketi and Pheidole pallidula (Nylander, 1849) (Hymenoptera: Formicidae) where neither ant species fed on $\mathrm{Hb}$-killed insects.

In conclusion, it was observed that SDF does influence the feeding behavior of some ant species and not in other species. Besides, different colonies of the same ant species have varying responses to SDF and this may be due to prior experience. It was determined that eight ant species fed significantly less on $\mathrm{Hb}$-killed insects than freezekilled insects, whereas only L. occidentale consumed significantly more $H b$-killed insects than freeze-killed insects. However, It was assumed that attack of the phorid flies affected it's response to cadavers. On the other hand, there was no significant difference in cadaver consumption with four species. It was also observed that four ant species took $H b$-killed insects into the nests but P. subdentatus and $M$. meridionalis removed the cadavers after $30 \mathrm{~min}$, whereas $C$. nodus, and F. fusca retained the cadavers in the nest. Further studies need to be conducted to explain why $L$. occidentale, C. nodus and F. fusca are not deterred by SDF and whether other ant species in the Formicinae as well as other species in other subfamilies have similar responses.

ACKNOWLEDGEMENTS. We thank P. Ward, University of California-Davis, Department of Entomology and Nematology, USA and K. Kiran, Trakya University, Department of Biology, Turkey for identification of ant species in our experiments and S. Tunc Kaya, Duzce University, Department of Biology for his assistance in the statistical analyses. B. Gulcu was supported by the 2219-Postdoctoral Scholarships for Turkish Citizens by the Scientific and Technological Research Council of Turkey (Tubitak) to the University of California, Davis.

AUTHOR CONTRIBUTIONS. Conceived and designed the experiments: BG, HKK. Performed the experiments: BG. Analyzed the 
data: EEL. Contributed reagents/materials/analysis tools: BG. Wrote the paper: BG, SH, HKK.

\section{REFERENCES}

Adams B.J. \& NGuyen K.B. 2002: Taxonomy and systematic. In Gaugler R. (ed.): Entomopathogenic Nematology. CABI, Wallingford, pp. 1-33.

Baur M.E., Kaya H.K. \& Strong D.R. 1998: Foraging ants as scavengers on entomopathogenic nematode-killed insects. Biol. Contr. 12: 231-236.

Boemare N. \& Akhurst R. 2006: The genera Photorhabdus and Xenorhabdus. In Dworkin M., Falkow S., Rosenberg E., Schleifer K.-H. \& Stackebrandt E. (eds): The Prokaryotes: Vol. 6: Proteobacteria: Gamma Subclass. Springer Science+Business Media, New York, pp. 451-494.

Bode H.B. 2009: Entomopathogenic bacteria as a source of secondary metabolites. - Curr. Opin. Chem. Biol. 13: 224-230.

Brian M.V., Elmes G. \& Kelly F.A. 1967: Populations of the ant Tetramorium caespitum Latreille. - J. Anim. Ecol. 36: 337-342.

Collingwood C.A. 1979: The Formicidae (Hymenoptera) of Fennoscandia and Denmark. - Fauna Entomol. Scand. 8: 1-174.

Cuezzo F. \& Guerrero R.J. 2012: The ant genus Dorymyrmex Mayr in Colombia. - Psyche 2012: 516058, 24 pp.

Drees B.M. \& JaCKMAN J.A. 1998: A Field Guide to Common Texas Insects. Gulf Publishing Company, Houston, TX, 359 pp.

Ekmen Z.I., Hazir S., Cakmak I., Ozer N., Karagoz M. \& Kaya H.K. 2010a: Potential negative effects on biological control by Sancassania polyphyllae (Acari: Acaridae) on an entomopathogenic nematode species. - Biol. Contr. 54: 166-171.

Ekmen Z.I., CakmaK I., Karagoz M., Hazir S., Ozer N. \& Kaya H.K. 2010b: Food preference of Sancassania polyphyllae (Acari: Acaridae): living entomopathogenic nematodes or insect tissues? - Biocontr. Sci. Technol. 20: 553-566.

Evans H.C. 1982: Entomogenous fungi in tropical forest ecosystem - An appraisal. - Ecol. Entomol. 7: 47-60.

Evans H.C. \& SAmson R.A. 1982: Cordyceps species and their anamorphs pathogenic on ants (Formicidae) in tropical forest ecosystem I. The Cephalotes (Myrmicinae) complex. - Trans. Br. Mycol. Soc. 79: 431-453.

FEener D.H. JR. 2000: Is the assembly of ant communities mediated by parasitoids? - Oikos 90: 79-88.

Fenton A., Magoolagan L., Kennedy Z. \& Spencer K.A. 2011: Parasite-induced warning coloration: a novel form of host manipulation. - Anim. Behav. 81: 417-422.

FitTKaU E.J. \& KLINGe H. 1973: On biomass and trophic structure of the central Amazonian rain forest ecosystem. - Biotropica 5: 2-14.

Foltan P. \& Puza V. 2009: To complete their life cycle, pathogenic nematode-bacteria complexes deter scavengers from feeding on their host cadaver. - Behav. Process. 80: 76-79.

Gulcu B., HaziR S. \& KaYA H.K. 2012: Scavenger deterrent factor (SDF) from symbiotic bacteria of entomopathogenic nematodes. - J. Invertebr. Pathol. 110: 326-333.

Hazir S., Kaya H.K., Stock S.P. \& Keskin N. 2003: Entomopathogenic nematodes (Steinernematidae and Heterorhabditidae) for biological control of soil pests. - Turk. J. Biol. 27: 181-202.

Hinchliffe S.J., Hares M.C., Dowling A.J. \& Ffrench-Constant R.H. 2010: Insecticidal toxins from the Photorhabdus and Xenorhabdus bacteria. - Open Toxinol. J. 3: 101-118.

Hoey-Chamberlain R. \& Rust M.K. 2014: Food and bait preferences of Liometopum occidentale (Hymenoptera: Formicidae). —J. Entomol. Sci. 49: 30-43.
Hölldobler B. \& Wilson E.O. 1990: The Ants. Harvard Univ. Press, Cambridge, MA, 746 pp.

HumAn K.G. \& GoRdon D.M. 1996: Exploitation and interference competition between the invasive Argentine ant, Linepithema humile, and native ant species. - Oecologia 105: 405-412.

IBM CORP RELEASED 2013: IBM SPSS Statistics for Windows Version 22.0. IBM Corp. Armonk, NY

Jones R.S., Fenton A. \& Speed M.P. 2016: Parasite-induced aposematism protects entomopathogenic nematode parasites against invertebrate enemies. - Behav. Ecol. 27: 645-651.

KAYA H.K. \& GaUGLER R. 1993: Entomopathogenic nematodes. - Annu. Rev. Entomol. 38: 181-206.

KaYA H.K. \& Sтоск S.P. 1997: Techniques in insect nematology. In Lacey L.A. (ed.): Manual of Techniques in Insect Pathology. Academic Press, San Diego, CA, pp. 281-324.

Oi D.H. \& Pereira R.M. 1993: Ant behaviour and microbial pathogens (Hymenoptera: Formicidae). — Fla Entomol. 96: $63-74$.

Pankewitz F. \& Hilker M. 2008: Polyketides in insects: ecological role of these widespread chemicals and evolutionary aspects of their biogenesis. - Biol. Rev. 83: 209-226.

Pereira R.M. \& Stimac J.L. 1992: Transmission of Beauveria bassiana within artificial nests of Solenopsis invicta (Hymenoptera: Formicidae) in the laboratory. - Environ. Entomol. 21: 1427-1432.

Porter S.D., Pesquero M.A., Campiolo S. \& Fowler H.G. 1995a: Growth and development of phorid fly maggots in the heads of Solenopsis fire ant workers (Hymenoptera: Formicidae). Environ. Entomol. 24: 475-479.

Ramalingam K.R., Dilipkumar A., Gulcu B., Manickam R., Pachiappan P., Sivaperumal S., Kaya H.K. \& Hazir S. 2017: Response of three cyprinid fish species to the Scavenger Deterrent Factor produced by the mutualistic bacteria associated with entomopathogenic nematodes. - J. Invertebr. Pathol. 143: 40-49.

Siebeneicher S.R., Vinson S.B. \& Kenerley C.M. 1992: Infection of the red imported fire ant by Beauveria bassiana through various routes of exposure. - J. Invertebr. Pathol. 59: 280-285.

Storey G.K. 1990: Chemical Defenses of the Fire Ant Solenopsis invicta Buren, against Infection by the Fungus Beauveria bassiana (Balsamo) Vuill. PhD. Thesis, University of Florida, Gainesville, $78 \mathrm{pp}$.

SudD J.H. \& FRANKS N.R. 2013: The Behavioural Ecology of Ants. Springer Science \& Business Media, New York, pp. 24-39.

Tobias N.J., Wolff H., Duahanschiri B., Grundmann F., Kronenwerth M., Shi Y.M., Simonyi S., Grun P., Shapiro-Ilan D., Pidot S.J., Stinear T.P., Ebersberger I. \& Bode H.B. 2017: Natural product diversity associated with the nematode symbionts Photorhabdus and Xenorhabdus. - Nat. Microbiol. 2: 1676-1685.

Ulug D., Hazir S., Kaya H.K. \& Lewis E.E. 2014: Natural enemies of natural enemies: The potential top-down impact of predators on entomopathogenic nematode populations. Ecol. Entomol. 39: 462-469.

Ward P.S., Blaimer B.B. \& Fisher B.L. 2016: A revised phylogenetic classification of the ant subfamily Formicinae (Hymenoptera: Formicidae), with resurrection of the genera Colobopsis and Dinomyrmex. - Zootaxa 4072: 343-357.

Zhou X.S., Kaya H.K., Heungens K. \& Goodrich-Blair H. 2002: Response of ants to a deterrent factor(s) produced by the symbiotic bacteria of entomopathogenic nematodes. - Appl. Environ. Microbiol. 68: 6202-6209.

Received January 22, 2018; revised and accepted May 25, 2018 Published online June 20, 2018 